\title{
Inhibition of p38 MAPK-dependent bronchial contraction after ozone by corticosteroids
}

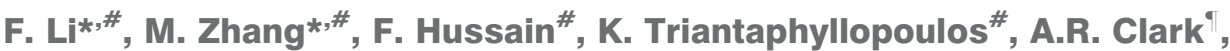 \\ P.K. Bhavsar ${ }^{\#}$, X. Zhou* and K.F. Chung ${ }^{\#}$
}

ABSTRACT: We determined the role of p38 mitogen-activated protein kinase (MAPK) in the increased airway smooth muscle (ASM) contractile responses following ozone and modulation by corticosteroids.

Mice were exposed to air or ozone $(3 \mathrm{ppm}$ for $3 \mathrm{~h})$ and isometric contractile responses of bronchial rings to acetylcholine (ACh) were measured using a myograph in the presence of p38 MAPK inhibitor, SB239063 $\left(10^{-6} \mathrm{M}\right)$ or dexamethasone $\left(10^{-6} \mathrm{M}\right)$. Because MAPK phosphatase (MKP)-1 is a negative regulator of p38 MAPK, we also studied these effects in MKP-1/- mice.

Bronchial rings from ozone-exposed wild-type and $\mathrm{MKP}-1^{-/-}$mice showed increased contractile responses, with a leftward shift of the dose-response curve in MKP-1 ${ }^{-/-}$mice. SB239063 inhibited bronchial contraction equally in air- and ozone-exposed C57/BL6 and MKP-1/- mice. Dexamethasone inhibited $\mathrm{ACh}$-induced bronchial contraction in both air- and ozone-exposed C57/BL6 mice, but not in air- or ozone-exposed MKP-1 ${ }^{-/-}$mice. ACh-stimulated p38 MAPK and heat shock protein (HSP)27 phosphorylation, as measured by Western blotting, and this effect was suppressed by SB239063 in C57/BL6 and MKP-1/-- mice, but not by dexamethasone in either airor ozone-exposed MKP-1//- mice.

p38 MAPK plays a role in maximal ACh-induced isometric contractile responses and increased contractility induced by ozone. Dexamethasone inhibits ACh-induced ASM contraction through phosphorylation of p38 MAPK and HSP27.

KEYWORDS: Acetylcholine, airway smooth muscle, dexamethasone, heat shock protein 27, p38 mitogen-activated protein kinase, mitogen-activated protein kinase phosphatase-1

$\mathbf{T}$ he mitogen-activated protein kinases (MAPKs) are a family of serine/threonine kinases that consists of three members, p38 MAPK, c-Jun N-terminal kinases (JNK) and extracellular signal-regulated protein kinase (ERK). MAPKs are activated by phosphorylation of specific tyrosine and threonine residues in their active domains. p38 MAPK is activated by inflammatory cytokines and cellular stresses, including oxidative stress, and is involved in cellular processes such as cell proliferation, apoptosis and inflammation [1, 2]. Its role in airway smooth muscle (ASM) contractile responses is less clear. p38 MAPK is expressed in ASM and other smooth muscles, such gastrointestinal smooth muscle, and becomes activated during acetylcholine (ACh)induced contraction [3-5]. Subsequent to this p38 MAPK activation is the downstream activation of MAPK-activated protein kinase-2 (MK2), which in turn leads to the phosphorylation of heat shock protein (HSP)27. HSP27 may associate with proteins, such as actomyosin and tropomyosin, involved in ASM contraction [5, 6]. Inhibition of p38 MAPK has been reported to increase force fluctuation-induced relengthening in maximally activated shortened bovine tracheal smooth muscle strips, an effect that involves the stabilisation of cytoskeletal remodelling [7]. In addition, p38 MAPK appears to be important in the bronchial hyperresponsiveness induced by the oxidant ozone [8] or allergic inflammation [9, 10]. The process of bronchial hyperresponsiveness could be secondary to enhanced ASM contractile responses, particularly after ozone exposure [11]. This is similar to the direct effect of the inflammatory cytokines interleukin- $1 \beta$ and tumour necrosis factor (TNF) $\alpha$ in increasing ASM contractility to ACh $[12,13]$, changes that were also prevented by pre-exposure to the glucocorticoid dexamethasone [13].

\section{AFFILIATIONS}

${ }^{*}$ Dept of Respiratory Medicine, The Affiliated First People's Hospital of Shanghai, Jiao Tong University,

Shanghai, China.

"Experimental Studies, Section of Airway Disease, National Heart and Lung Institute, and

- Kennedy Institute of Rheumatology Division, Imperial College, London, UK.

\section{CORRESPONDENCE}

$X$. Zhou

Dept of Respiratory Medicine The Affiliated First People's Hospital of Shanghai Jiao Tong University 100 Haining Road Shanghai 200080

China

E-mail: xzhou53@163.com

Received:

Feb 072010

Accepted after revision: July 122010 First published online: Aug 062010 
The inactivation of MAPKs such as p38 is partly dependent on MAP kinase phosphatases (MKPs), also referred to as dual-specificity phosphatases, particularly MKP-1, which also deactivates other MAPK members, including JNK [14, 15]. MKP-1 is upregulated by the environmental pollutant ozone and proinflammatory cytokines, thereby limiting MAPK activation through a feedback mechanism. In addition, corticosteroids (CS) very rapidly upregulate the expression of MKP-1 in inflammatory cells and ASM [16-18], raising the possibility that MKP-1 could mediate relaxant effects on ASM contractile responses in a manner dependent on the activation of MAPKs, particularly p38.

In the present study, we examined the role of p38 MAPK in the enhanced isometric contractile responses of bronchi induced by exposure to ozone and the effect of CSs on those responses by studying the effect of $\mathrm{p} 38$ MAPK inhibitors, MKP-1 knockdown and $\mathrm{MKP}-1^{-/-}$mice. Our data indicate that both baseline and enhanced maximal isometric contractile cholinergic responses are dependent on p38 MAPK activation, and that the relaxant effect of CSs may be mediated through MKP-1.

\section{METHODS}

\section{Reagents}

ACh, 5-hydroxytryptamine (5-HT), indomethacin, SB239063 (p38 MAPK inhibitor), PD98059 (ERK inhibitor), SP600125 (JNK inhibitor) and dexamethasone were obtained from SigmaAldrich (Poole, UK). SD282, another p38 MAPK inhibitor, was a gift from Scios Inc. (Fremont, CA, USA). Rabbit anti-phosphop38 MAPK and anti-p38 MAPK, and rabbit anti-phospho-HSP27 and anti-HSP27 were obtained from Cell Signalling Technology (Beverly, MA, USA). Horseradish peroxidase (HRP)-conjugated anti-rabbit immunoglobulin was obtained from Dakocytomaton (Glostrup, Denmark). ECL Plus was obtained from GE Healthcare (Slough, UK) and Re-Blot Plus Mild Solution from Millipore (Billerica, MA, USA).

\section{Mice}

Pathogen-free, male, 10-14-week-old MKP-1 ${ }^{-/-}$mice, obtained from the Kennedy Institute of Rheumatology (Imperial College, London, UK) were used. MKP-1 ${ }^{-/-}$mice were on a mixed C57/ BL6-129/Sv genetic background and were backcrossed over nine generations, then intercrossed with heterozygotes [19]. $\mathrm{MKP}-1^{-/-}$mice were identified by PCR-based screening of genomic DNA from tail tips. Pathogen-free, male, 10-14-weekold C57/BL6 mice purchased from Harlan (Bicester, UK) were used as wild-type controls. The animals were housed in the BioSciences facilities of Imperial College, under controlled temperature $\left(20^{\circ} \mathrm{C}\right)$ and humidity $(40-60 \%)$, in a 12-h light/ 12-h dark cycle with food and water supplied ad libitum. The protocols and procedures used in the study were approved by the Animal Ethics Committee of Imperial College in compliance with UK Home Office regulations.

\section{Ozone exposure}

Mice were exposed to filtered air or to ozone generated from an Ozoniser (Model 500; Sander Ozoniser, Wuppertal, Germany), mixed with filtered air at a concentration of 3 ppm in a sealed Perspex container, as described previously [20]. Ozone concentration was continually monitored using an ozone probe (ATi Technologies, Oldham, UK) placed within the box.

\section{Bronchial ring preparation and myography}

$24 \mathrm{~h}$ after exposure, mice were sacrificed by cervical dislocation. Lungs were rapidly removed from the chest and immersed in physiological salt solution (PSS; $119 \mathrm{mM} \mathrm{NaCl}, 4.7 \mathrm{mM} \mathrm{KCl}$, $2.5 \mathrm{mM} \mathrm{CaCl}_{2}, 1.17 \mathrm{mM} \mathrm{MgSO} 4,25 \mathrm{mM} \mathrm{NaHCO}, 1.18 \mathrm{mM}$ $\mathrm{KH}_{2} \mathrm{PO}_{4}, 0.027 \mathrm{mM}$ EDTA, and $5.5 \mathrm{mM}$ glucose). Intrapulmonary bronchi from the left lobe were dissected under the microscope, and parenchymal and connective tissues were carefully removed [21]. Segments of bronchi, 200-400 $\mu \mathrm{m}$ in diameter and $2 \mathrm{~mm}$ in length, were mounted on the metal prongs of a wire myograph (610M; Danish Myo Technology, Aarhus, Denmark), suspended in an organ bath, filled with $5 \mathrm{~mL}$ of PSS, bubbled with $95 \%$ oxygen and maintained at $37^{\circ} \mathrm{C}$. The isometric tension was recorded and analysed using Chart software (AD Instruments Ltd, Hastings, UK). The optimal length for each bronchial ring taken at the point at which increased stretch ceased to increase active tension was obtained from active length-tension responses. In brief, bronchi were first stretched to $0.5 \mathrm{mN}$ and then were sequentially stretched by $200-\mu \mathrm{m}$ length increments (passive tension) and stimulated to contract actively (active tension) with $124 \mathrm{mM}$ potassium PSS (KPSS). Optimal length was defined as the point at which increased stretch ceased to increase active tension. Bronchi were then allowed to equilibrate for $30 \mathrm{~min}$ in PSS; $3 \mu \mathrm{M}$ indomethacin was added into the organ bath to inhibit epithelial prostaglandin release. The first bronchial contractile response was generated with $10^{-9}-10^{-3} \mathrm{M}$ ACh or $10^{-9}-10^{-4} \mathrm{M} 5$-HT. The effect of test compounds on the bronchial contractile response was assessed in bronchi from air- and ozone-exposed mice. Bronchi were washed four times with PSS, incubated with the p38 MAPK inhibitor SB239063 or SD282, ERK inhibitor PD98059, JNK inhibitor SP600125 or dexamethasone for $1 \mathrm{~h}$, and then a second contractile response test was performed. We also studied PF-3644022, an inhibitor of MK2, which is a direct downstream substrate of p38 kinase, [22]. The concentrationresponse curves were fitted to a nonlinear regression with the Hill equation (GraphPad Prism 4.03, San Diego, CA, USA) to provide an estimated maximal contraction (Emax) and the negative logarithm of the effective concentration to cause $50 \%$ of the maximal contractile response (pEC50).

\section{Western blotting}

Intrapulmonary bronchi were dissected, mounted onto two metal prongs and immersed in PSS. After reaching optimal tension with KPSS, each bronchus was incubated with SB239063 $\left(10^{-6} \mathrm{M}\right)$, dexamethasone $\left(10^{-6} \mathrm{M}\right)$ or neither for $1 \mathrm{~h}$ in the organ bath, and then $10^{-3} \mathrm{M}$ ACh was added for $5 \mathrm{~min}$. Bronchial samples were snap-frozen in liquid nitrogen. The frozen samples were homogenised in extraction buffer $(50 \mathrm{mM}$ tris-(hydroxymethyl)-aminomethane (Tris), 0.5\% Triton X-100, $150 \mathrm{mM} \mathrm{NaCl}, 1 \mathrm{mM}$ EDTA, $20 \mathrm{mM} \mathrm{Na}_{3} \mathrm{VO}_{4}$ and protease inhibitor cocktail) by sonication on ice for a few seconds. After sonication and centrifugation $(8,000 \times g(15,000 \mathrm{rpm}) ; 15 \mathrm{~min})$, the supernatants were collected. Equal amounts of protein (10 $\mu$ g per lane) were loaded onto 10\% Bis-Tris gel (NuPAGE; Invitrogen, Paisley, UK). Electrophoresis was performed for $45 \mathrm{~min}$ at $150 \mathrm{~V}(40 \mathrm{~mA})$ and the separated proteins transferred to nitrocellulose membrane with dry blotting system (iBlot; Invitrogen, Paisley, UK). The membrane was blocked with $5 \%$ non-fat dry milk for $1 \mathrm{~h}$ at room temperature and incubated with rabbit anti-phospho-p38 MAPK or 


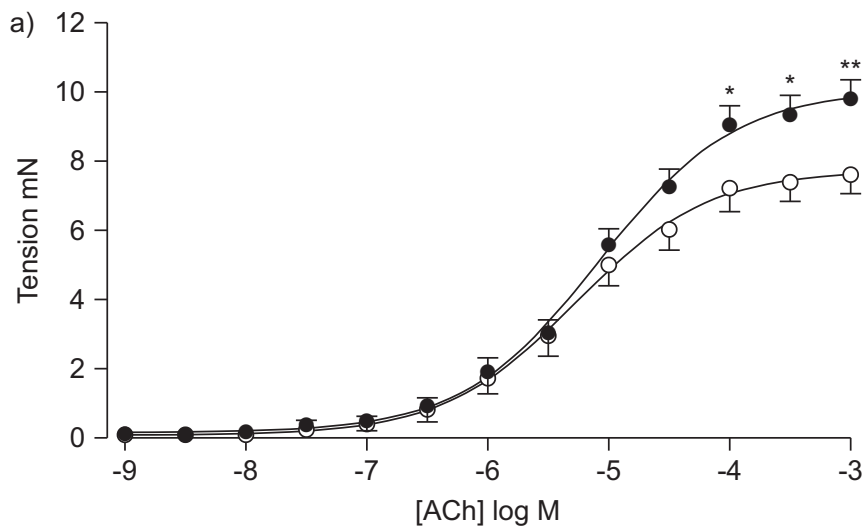

b)

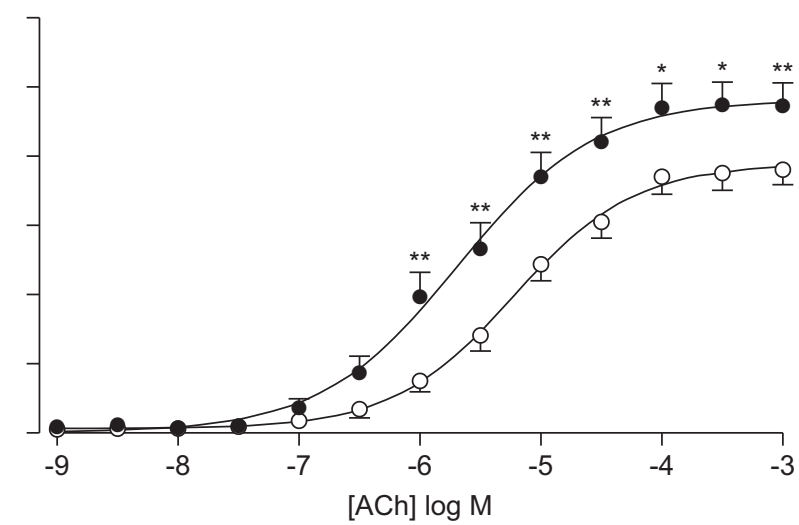

FIGURE 1. Acetylcholine (ACh)-induced isometric bronchial contractile tension in air-

and ozone-exposed $(\bigcirc)$ a) C57/BL6 mice (12 in air- and nine ozone-exposed) and b) mitogen-activated protein kinase phosphatase (MKP) $-1^{-1-}$ mice (11 in air- and nine ozone-exposed). Data presented as mean \pm SEM. ${ }^{*}$ : $p<0.05$ compared with airexposed group; **: $p<0.01$ compared with air-exposed group.

anti-phospho-HSP27 antibodies (diluted 1:1,000) overnight at $4{ }^{\circ} \mathrm{C}$. Following incubation, the membrane was washed and incubated with HRP-conjugated anti-rabbit immunoglobulins for $2 \mathrm{~h}$ at room temperature, followed by development using ECL Plus. Band densities were quantified using a densitometer with Grab-It and Gel Work Software (UVP, Cambridge, UK). The membrane was stripped with Re-Blot Plus Mild Solution and re-probed with anti-p38 MAPK or anti-HSP27 antibodies $(1: 1,000)$. Densitometric results for p38 MAPK or HSP27
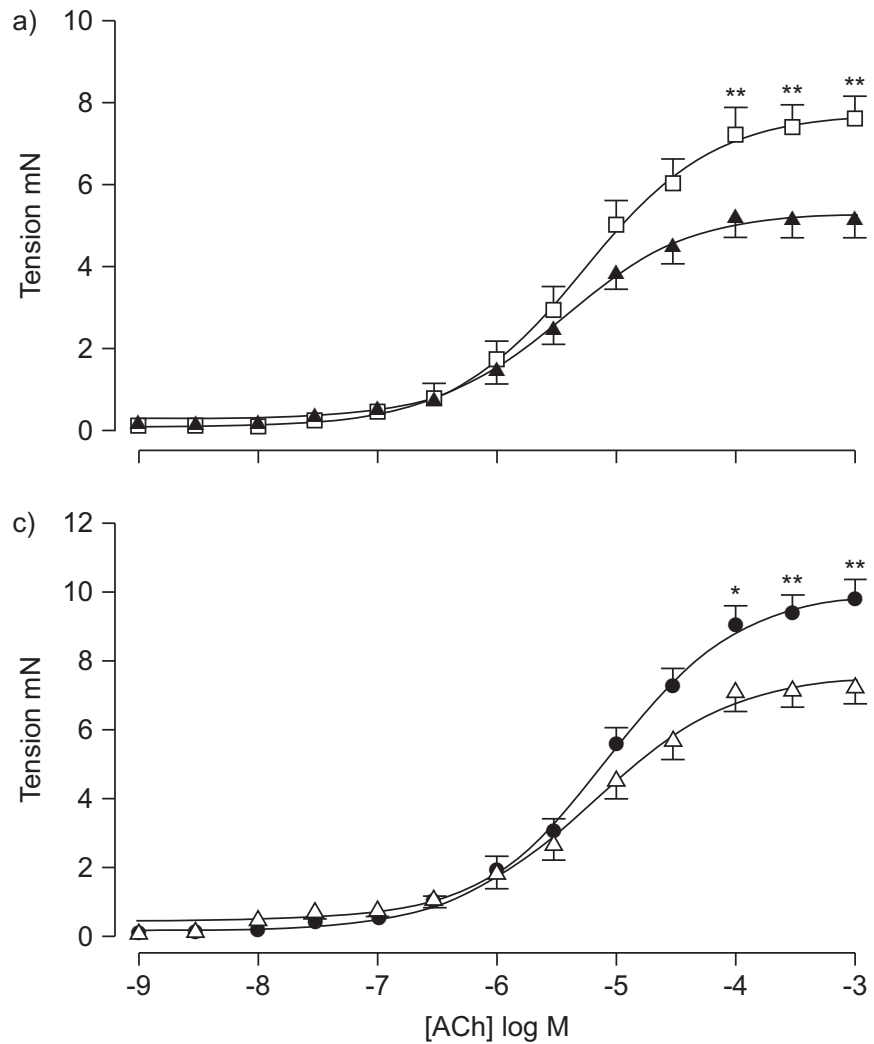

phosphorylation were expressed as a ratio of phosphorylated p38MAPK or HSP27 to nonphosphorylated p38 MAPK or HSP27, respectively.

To probe for MKP-1, we used a rabbit anti-MKP-1 (V-15; Santa Cruz Biotechnology Inc., CA, USA; 1:1,000) and incubated the membranes overnight at $4{ }^{\circ} \mathrm{C}$. The membrane was then stripped with Re-Blot Plus Mild Solution and reprobed with rabbit anti- $\alpha$-tubulin antibody (Cell

b)

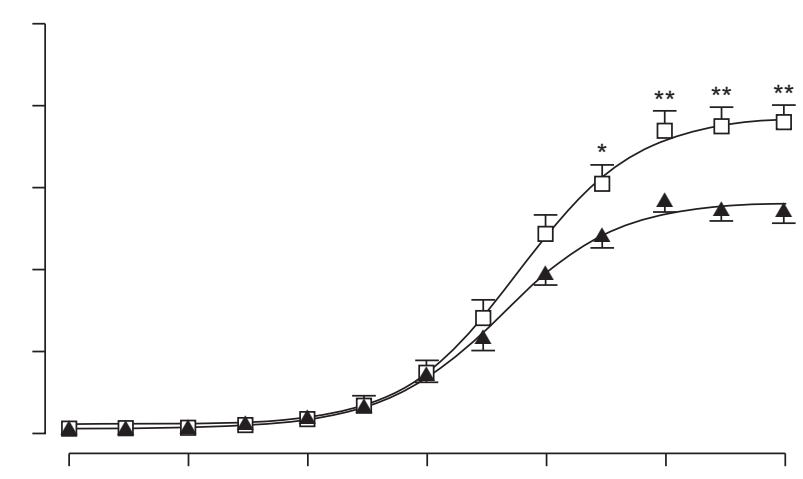

d)

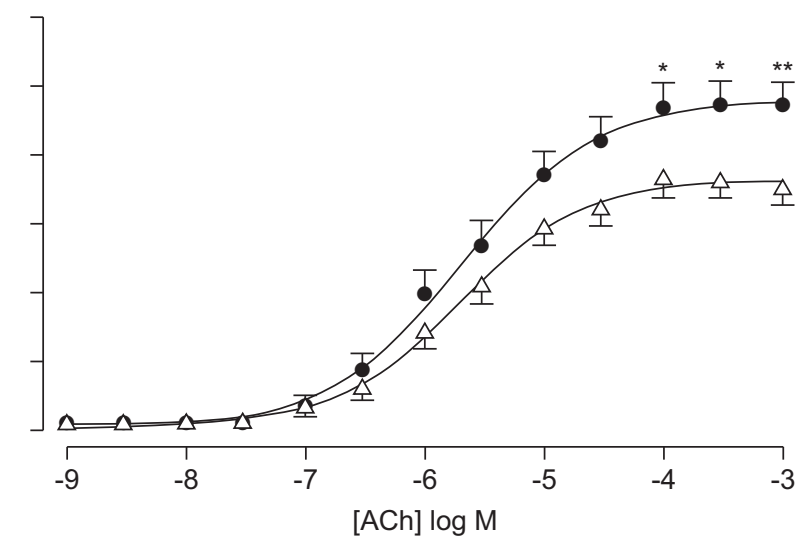

FIGURE 2. Effect of SB239063 (10-6 M) on acetylcholine (ACh)-induced bronchial contractile responses in air-exposed a) C57/BL6 mice ( $\mathrm{n}=12)$ and b) mitogen-activated protein kinase phosphatase (MKP) $-1 \%$ mice $(n=11)$, and in ozone-exposed c) C57/BL6 mice $(n=9)$ and d) MKP- $1 \%$ mice $(n=9)$. Data presented as mean \pm SEM. $\square:$ air; $\mathbf{\Lambda}:$ air plus SB230963; •: ozone; $\triangle$ : ozone plus SB230963. *: $p<0.05$ compared with untreated mice; ${ }^{* *}$ : $p<0.01$ compared with untreated mice. 

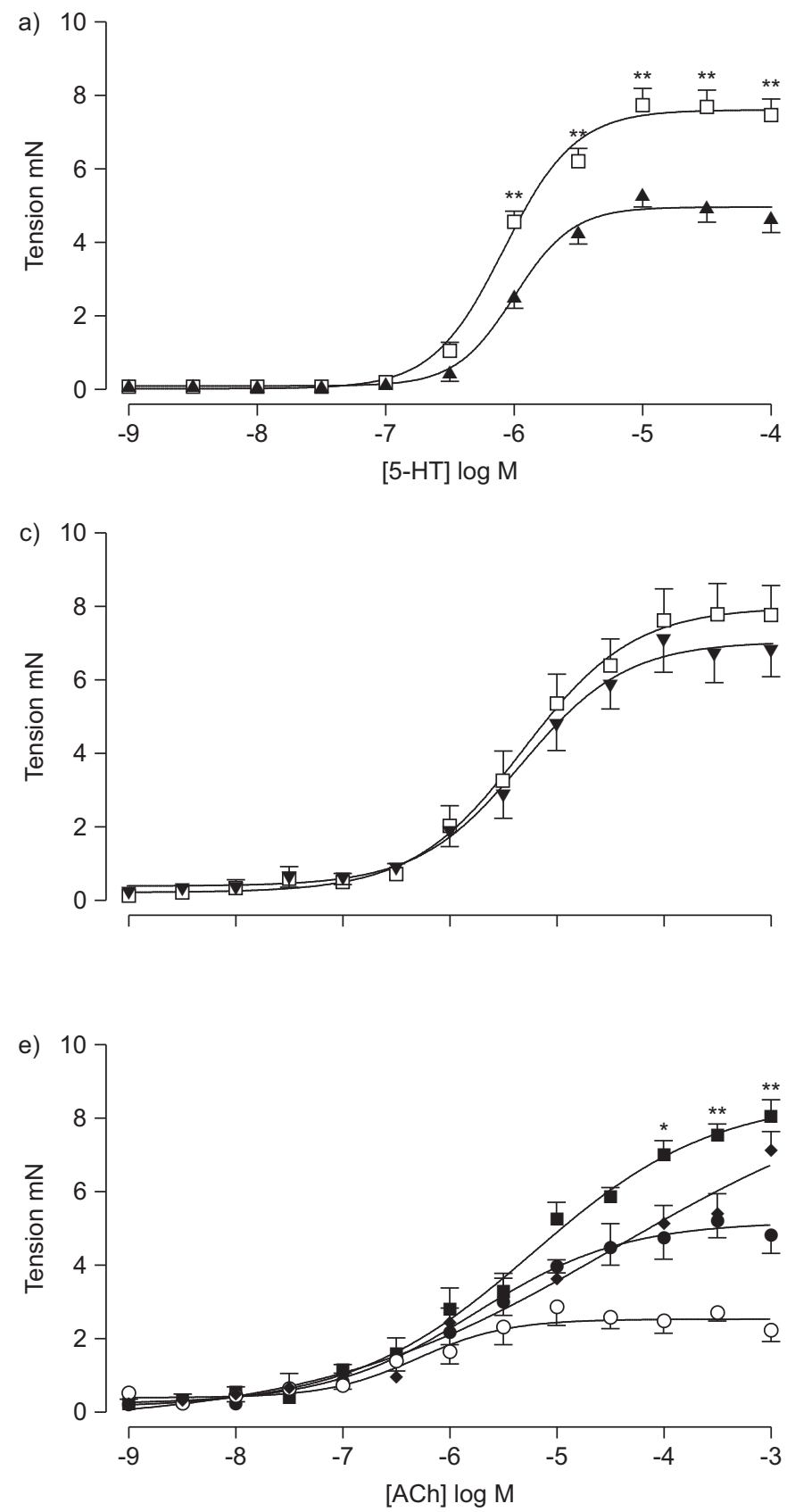

Signalling Technology, Beverly, CA, USA; 1:1,000). Densitometric results for MKP-1 were expressed as a ratio of MKP-1 to $\alpha$-tubulin.

\section{Data analysis}

Date are presented as mean \pm SEM. Unpaired t-tests and twoway ANOVA with Bonferroni correction were used to make a comparison between different groups as appropriate. p-values $<0.05$ were regarded as statistically significant.

\section{RESULTS}

\section{ACh-induced contractile response in ozone-exposed MKP $-1^{-/-}$mice}

Bronchial contractile responses to ACh $2 \mathrm{~h}$ apart in C57/BL6 and

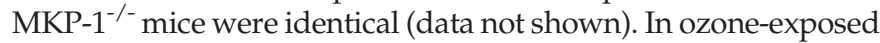

b)

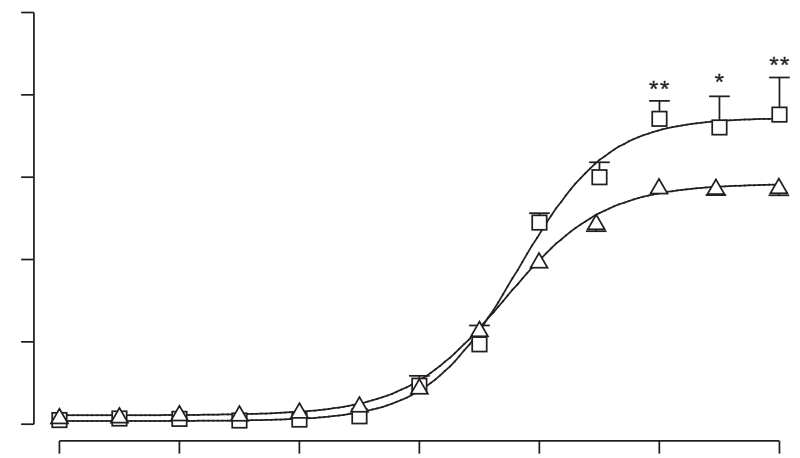

d)

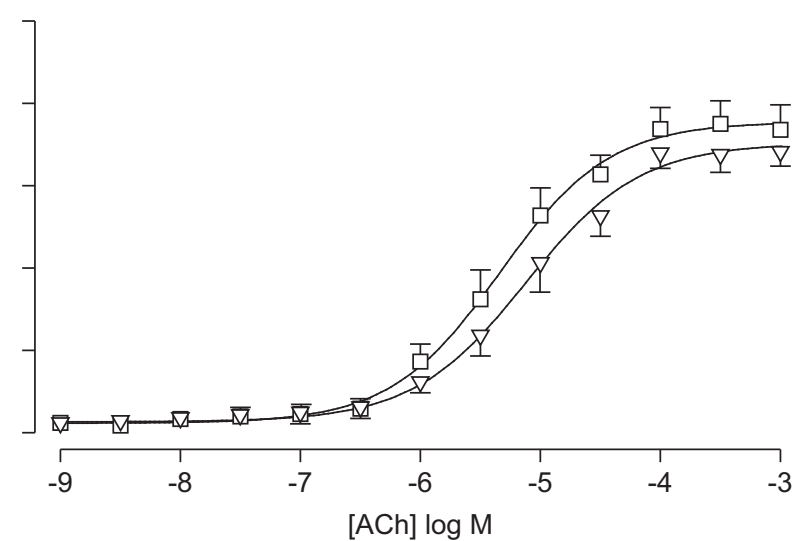

FIGURE 3. Inhibition of 5-hydroxytryptamine (5-HT)-induced bronchial contractile tension by a) p38 mitogen-activated protein kinase (MAPK) inhibitor SB239063 $\left(10^{-6} \mathrm{M}\right)$ in air-exposed mice $(n=6)$. Inhibition of acetylcholine (ACh)induced bronchial contraction by b) p38 MAPK inhibitor SD282 $\left(10^{-6} M ; n=3\right)$, c) extracellular signal-regulated kinase inhibitor PD98059 (10 $\mathrm{M} ; \mathrm{n}=6)$ and d) c-Jun N-terminal kinase inhibitor SP600125 $\left(10^{-6} \mathrm{M} ; \mathrm{n}=6\right)$ in air-exposed C57/BL6 mice. e) Effect of MAPK-activated protein kinase 2 inhibitor PF3644022 on AChinduced bronchial contractile tension in air-exposed C57/BL6 mice. Data are presented as mean \pm SEM. $\square$ : air; $\mathbf{\Lambda}$ : air plus SB239063; $\triangle$ : air pluS SD282; $\mathbf{\nabla}$ : air plus PD98059; $\nabla$ : air plus SP600125; $\boldsymbol{\square}$ : control; : 10-6 M PF3644022; $\bullet: 10^{-5} \mathrm{M}$ PF3644022; $O: 10^{-6} \mathrm{M}$ PF3644022. *: $\mathrm{p}<0.05$ compared with untreated mice; **: $p<0.01$ compared with untreated mice.

C57/BL6 mice, Emax was increased compared with air-exposed mice $(7.73 \pm 0.31$ versus $10.06 \pm 0.37 \mathrm{mN}$, respectively; $\mathrm{p}<0.05)$ but $\mathrm{pEC} 50$ values remained unchanged. In ozone-exposed MKP-1 ${ }^{-/-}$ mice, there was a similar enhancement of Emax $(7.76 \pm 0.27$ versus $9.62 \pm 0.40 \mathrm{mN}$, respectively; $\mathrm{p}<0.05)$, with a shift of the doseresponse curve to the left (pEC50 $5.69 \pm 0.14$ versus $5.25 \pm 0.11$; $\mathrm{p}<0.05$ ) (fig. 1).

\section{Effect of SB230963 and dexamethasone on ACh-induced bronchial contraction}

We used SB239063 to investigate the role of p38 MAPK in the increased contractile response after ozone. SB239063 inhibited the maximal contractile tension in a concentration-dependent fashion, with an inhibition of $9.8 \pm 3.6 \%$ at $10^{-8} \mathrm{M}, 20.7 \pm 7.4 \%$ at $10^{-7} \mathrm{M}$ (data not shown). SB239063 (10 $\left.{ }^{-6} \mathrm{M}\right)$ inhibited 


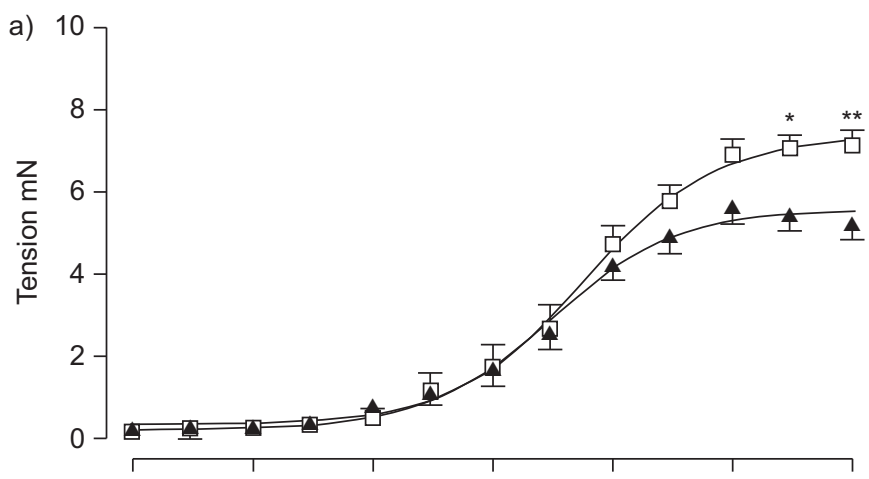

b)
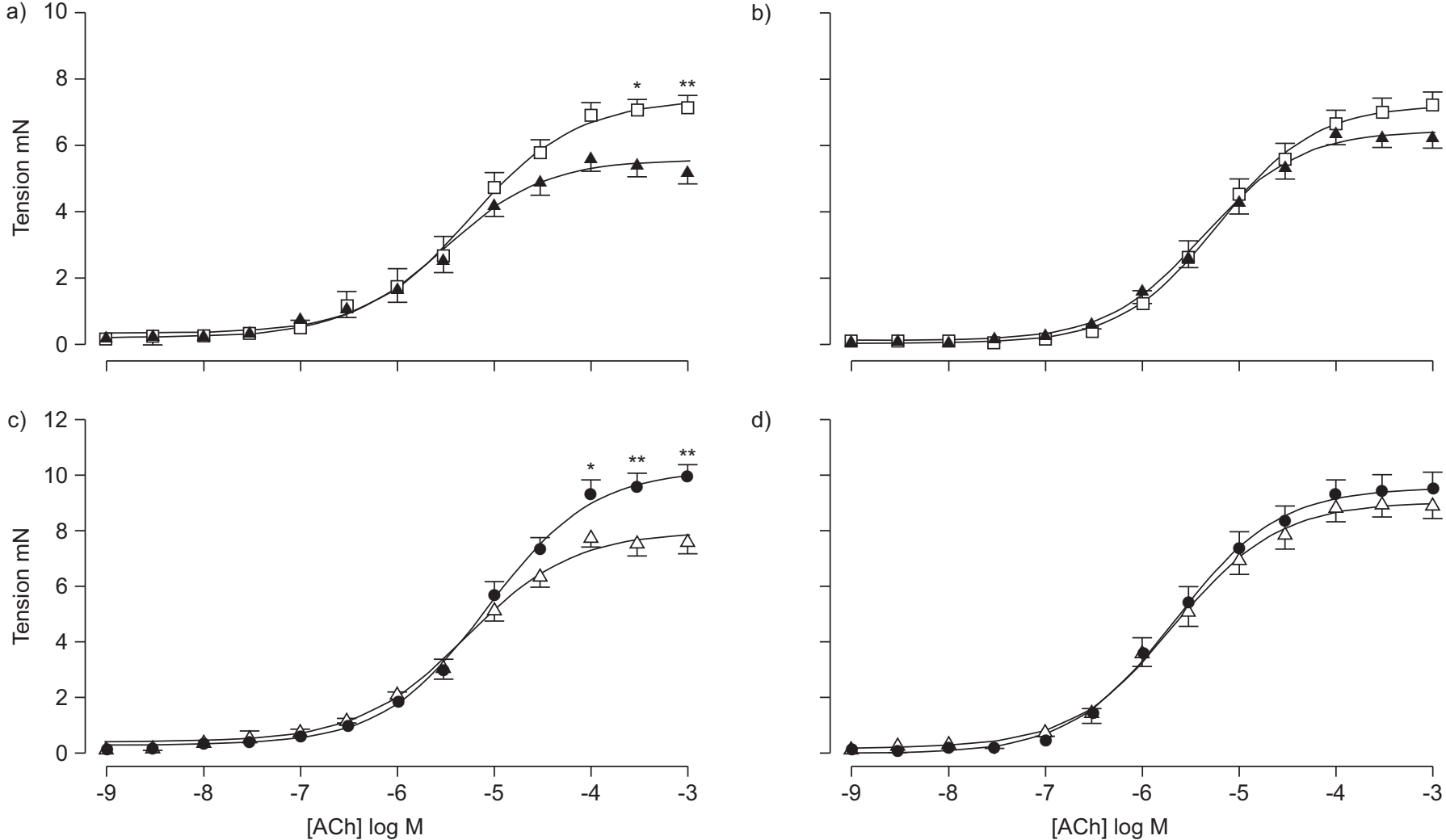

d)

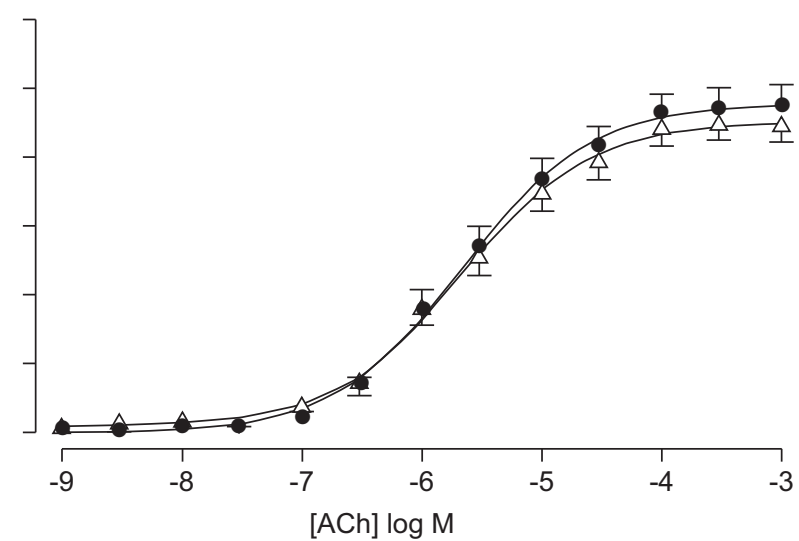

FIGURE 4. Effect of dexamethasone $\left(10^{-6} \mathrm{M}\right)$ on inhibition of acetylcholine (ACh)-induced bronchial contractile tension both in a) air-exposed C57/BL6 ( $\left.\mathrm{n}=11\right)$ and b) MKP-1\% mice $(n=11)$, and in ozone-exposed c) C57/BL6 mice $(n=9)$ and d) MKP-1\% mice $(n=9)$. Data are presented as mean \pm SEM. $\square$ : air; $\mathbf{\Lambda}$ : air plus dexamethasone; -: ozone; $\triangle$ : ozone plus dexamethasone. *: $p<0.05$ compared with untreated mice; ${ }^{*}$ : $p<0.01$ compared with untreated mice.

bronchial contraction in air-exposed C57/BL6 mice by $29.1 \pm 4.0 \%$, with no change in pEC50 ( $<<0.01$; fig $2 \mathrm{a})$. Because indomethacin was present in the bathing solution, we sought to determine whether it could have influenced the modulation of the contractile response by SB239063. However, we obtained the same inhibitory effect of SB239063 in the absence of indomethacin in the bathing solution, indicating lack of influence of prostaglandins (data not shown). This inhibition by SB239063 was also observed after contraction with another receptor-mediated constrictor, 5-HT, of the order of $30.9 \pm 5.0 \% \quad(p<0.01$; fig $3 a)$. Using another p38 MAPK inhibitor, SD282 $\left(10^{-6} \mathrm{M}\right)$, maximal response to ACh was also decreased by $23.6 \pm 5.3 \%$ ( $p<0.01$; fig. $3 b)$.

SB239063 also reduced bronchial contraction of bronchi from ozone-exposed C57/BL6 mice by $24.4 \pm 3.8 \%$ ( $p<0.01$; fig $2 b$ ). SB239063 also lowered Emax by $25.8 \pm 3.1 \%(p<0.01)$ and by $21.8 \pm 3.9 \%(\mathrm{p}<0.01)$ in air- and ozone-exposed $\mathrm{MKP}-1^{-/-}$mice, respectively (fig. $2 \mathrm{c}$ and $\mathrm{d}$ ).

We also investigated the role of ERK and JNK in ACh-induced bronchial contraction by using the ERK inhibitor PD98059 $\left(10^{-6} \mathrm{M}\right)$ and the JNK inhibitor SP600125 $\left(10^{-6} \mathrm{M}\right)$, respectively. Neither PD98059 nor SP600125 inhibited the maximal bronchial response (fig. $3 \mathrm{c}$ and d). In addition, we investigated whether PF-3644022 [22], an inhibitor of MK2, a direct downstream substrate of p38 kinase, had an effect. PF$3644022\left(10^{-7}-10^{-5} \mathrm{M}\right)$ dose-dependently also inhibited the maximal ACh-induced bronchial contraction (fig. 3e).
$10^{-6} \mathrm{M}$ dexamethasone inhibited bronchial contraction by $21.6 \pm$ $4.0 \%$ in air-exposed mice ( $<<0.01$; fig. $4 a$ ), while at $10^{-8}$ and $10^{-7} \mathrm{M}$, there was no effect (data not shown). Dexamethasone also reduced Emax by $19.9 \pm 3.9 \%$ in ozone-exposed C57/BL6 mice $(\mathrm{p}<0.01$; fig. $4 \mathrm{~b})$. However, in neither air- nor ozone-exposed $\mathrm{MKP}^{-1 /-}$ mice, was there any significant attenuation by dexamethasone $(8.9 \pm 2.5 \%$ and $5.9 \pm 1.6 \%$, respectively; not significant; fig. $4 \mathrm{c}$ and $\mathrm{d}$ ).

\section{p38 MAPK and HSP27 activation by ACh}

\section{Air-exposed mice}

In bronchial preparations from air-exposed C57/BL6 mice, ACh increased p38 MAPK (Thr ${ }^{180} / \mathrm{Tyr}^{182}$ ) and HSP27 $\left(\mathrm{Ser}^{82}\right.$ ) phosphorylation, measured as the ratio of phosphorylated p38 MAPK and HSP27 to total p38 MAPK and HSP27, respectively (fig. 5a and c). Both SB239063 and dexamethasone inhibited p38 MAPK and HSP27 phosphorylation in C57/BL6 mice. In air-exposed $\mathrm{MKP}-1^{-/-}$mice, the ratio of phosphorylated p38 MAPK to total p38 MAPK, and of phosphorylated HSP27 to total HSP27 increased in ACh-stimulated bronchial preparations $(p<0.05$ and $p<0.01$ respectively; fig. 5). SB239063, but not dexamethasone, inhibited ACh-induced p38 MAPK and HSP27 phosphorylation in MKP-1/- mice (fig. 5).

\section{Ozone-exposed mice}

The baseline levels of p38 MAPK and HSP27 phosphorylation were not significantly different between air- and ozone-exposed mice. p38 MAPK and HSP27 phosphorylation were increased in 
ACh-stimulated bronchial preparations in ozone-exposed C57/ BL6 mice ( $p<0.01$ and $p<0.05$, respectively; fig. 6$)$, although the increase was not different from that observed in air-exposed C57/BL6 mice. SB239063 and dexamethasone reduced p38 MAPK and HSP27 activation. ACh-stimulated p38 MAPK and HSP27 phosphorylation in bronchial preparations in ozoneexposed $\mathrm{MKP}-1^{-/-}$mice ( $\mathrm{p}<0.01$ and $\mathrm{p}<0.05$ respectively; fig. 6). In ozone-exposed MKP-1 ${ }^{-/-}$mice, while SB239063 reduced the p38 MAPK and HSP27 phosphorylation $(\mathrm{p}<0.01)$, dexamethasone did not (fig. 6).

\section{Effect of dexamethasone on MKP-1 expression}

We determined whether dexamethasone treatment of bronchial tissues would cause any changes in MKP-1 expression. We found that incubation of bronchial tissues from wild type mice with $\mathrm{ACh}\left(10^{-3} \mathrm{M}\right)$ caused no significant change in

a)
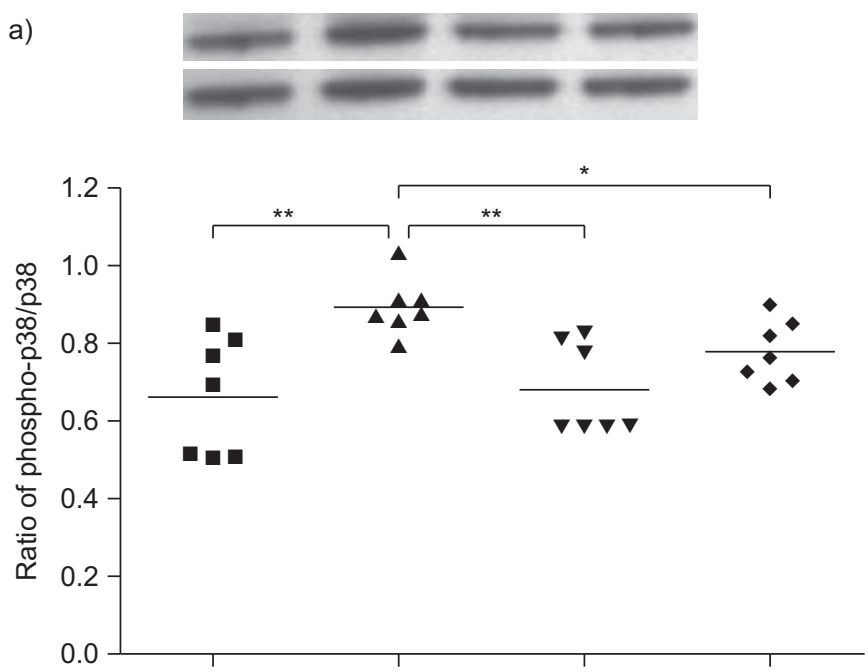

c)
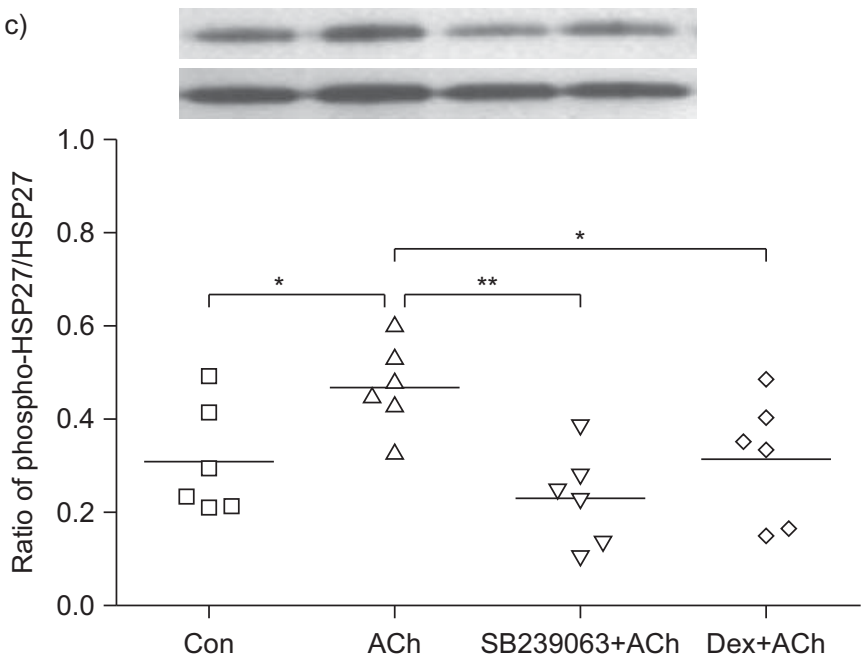

MKP-1 expression. However, after incubation with dexamethasone $\left(10^{-6} \mathrm{M}\right)$ and $\mathrm{ACh}\left(10^{-3} \mathrm{M}\right)$ for $1 \mathrm{~h}$, there was a significant increase in expression of MKP-1 (fig. 7). We found similar results in bronchial tissues obtained from ozoneexposed mice.

\section{DISCUSSION}

We have shown that the maximal isometric contractile response to ACh in isolated murine bronchi was inhibited by p38 MAPK inhibitors, indicating that p38 MAPK activation contributes to maximal ASM isometric contraction. Measurement of p38 phosphorylation confirmed the increase in activation of p38 MAPK. The other MAPKs, JNK and ERK, do not appear to be involved in this response. CSs inhibited maximal contractile responses, an effect that was absent in $\mathrm{MKP}-1^{-/-}$mice, where $\mathrm{p} 38$ MAPK activation would not be modulated by MKP-1, which is b)
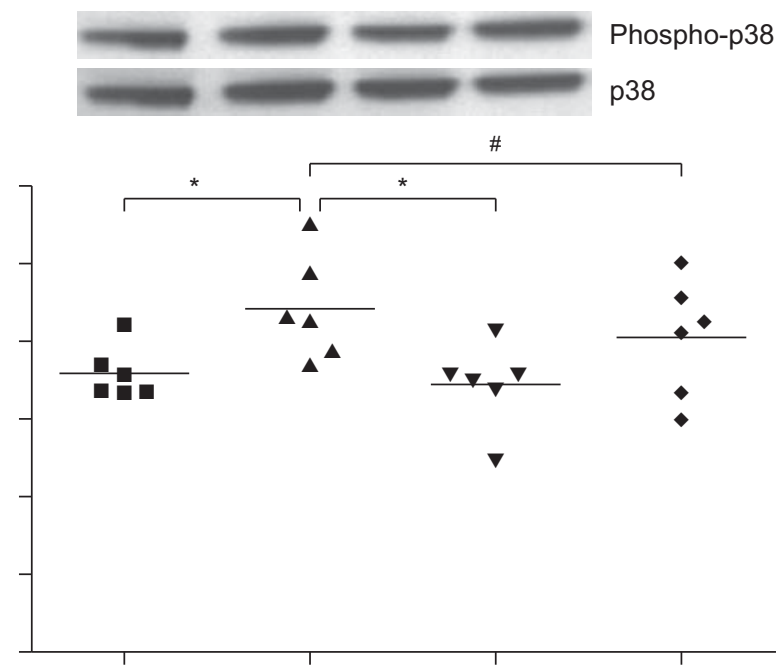

d)

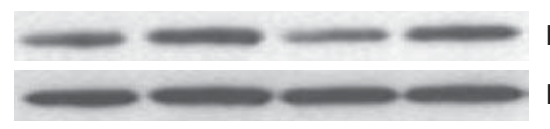

Phospho-HSP27

HSP27

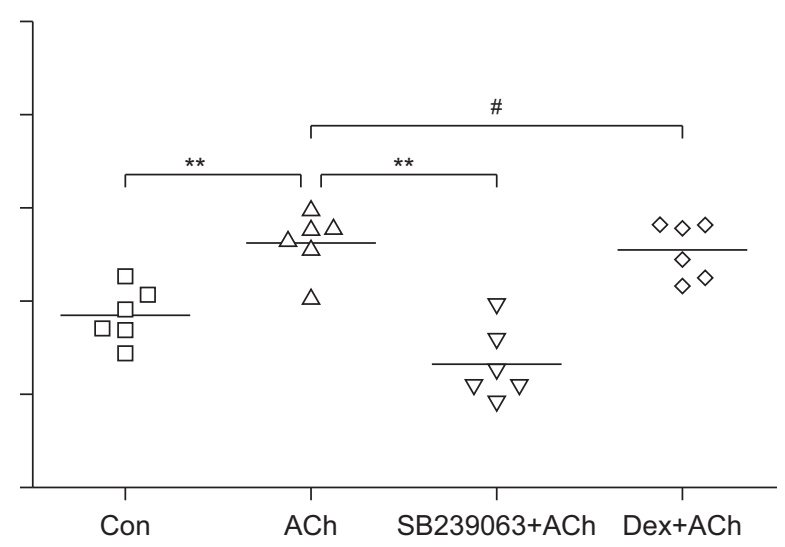

FIGURE 5. Western blot analysis of ratio of a, b) phosphorylated p38 mitogen-activated protein kinase (MAPK) to nonphosphoryated p38 MAPK and c, d) phosphorylated heat shock protein (HSP)27 to nonphosphoryated HSP27 in bronchial preparations that were unstimulated (Con), acetylcholine (ACh)-stimulated, or AChstimulated and pretreated with SB239063 $\left(10^{-6} \mathrm{M}\right.$ ) or dexamethasone (Dex; $10^{-6} \mathrm{M}$ ) from air-exposed a, c) C57/BL6 and b, d) MAPK phosphatase (MKP)- ${ }^{-/-}$mice. Each panel shows representative Western blots of phosphorylated p38 MAPK and nonphosphoryated p38 MAPK, or phosphorylated HSP27 to nonphosphoryated HSP27, with individual results of $n=6-7$ in each group. *: $p<0.05$ compared with ACh alone; **: $p<0.01$ compared with ACh alone; * : not significant. 
a)

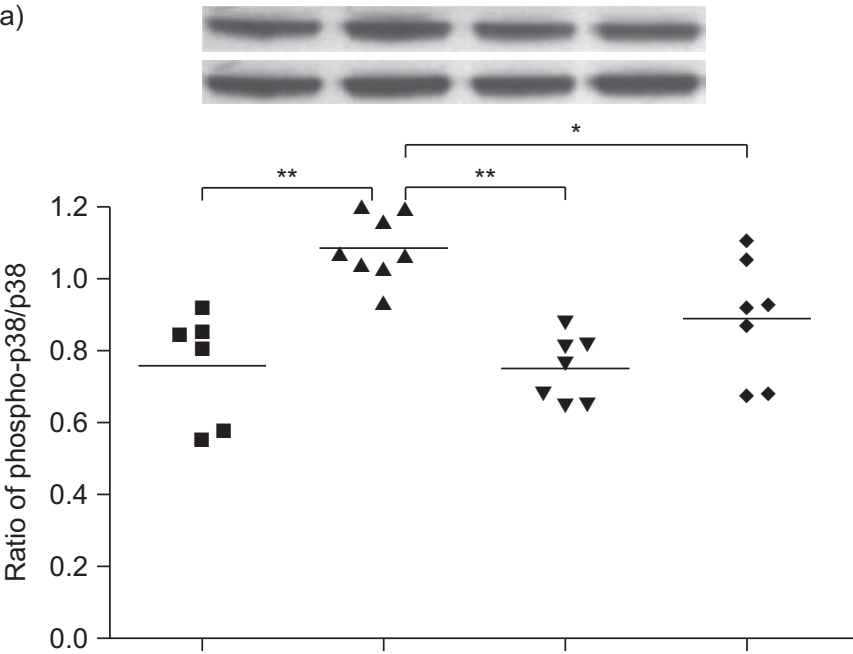

c)
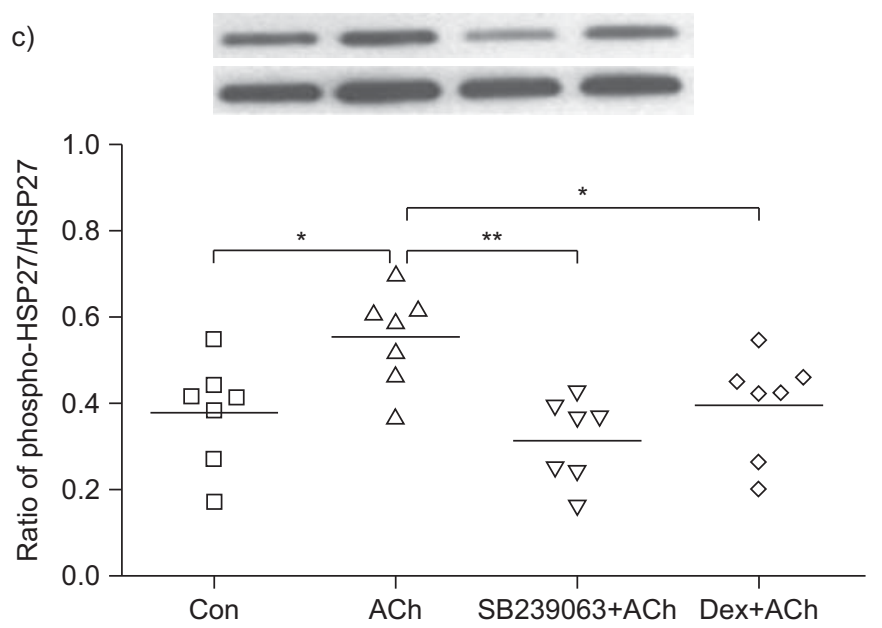

b)

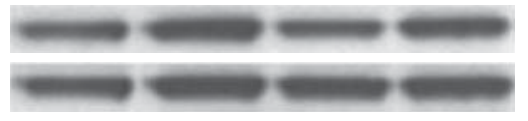

Phospho-p38

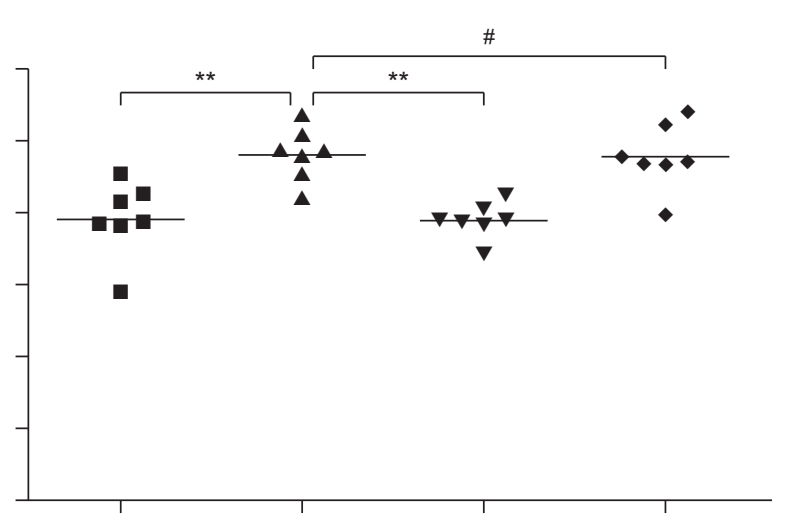

d)

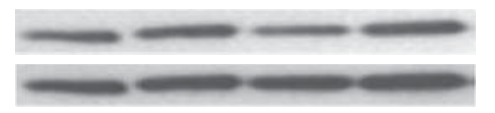

Phospho-HSP27

HSP27

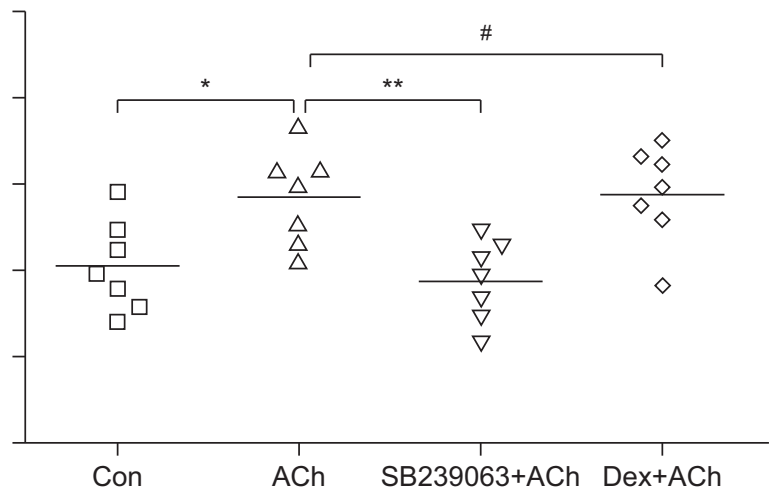

FIGURE 6. Western blot analysis of ratio of $a, b)$ phosphorylated p38 mitogen-activated protein kinase (MAPK) to nonphosphoryated p38 MAPK and c, d) phosphorylated heat shock protein (HSP)27 to nonphosphoryated HSP27 in bronchial preparations that were unstimulated (Con), acetylcholine (ACh)-stimulated, or AChstimulated and pretreated with SB239063 $\left(10^{-6} \mathrm{M}\right.$ ) or dexamethasone (Dex; $10^{-6} \mathrm{M}$ ) from ozone-exposed a, c) C57/BL6 and b, d) MAPK phosphatase (MKP)-1 ${ }^{-/}$mice. Each panel shows representative Western blots of phosphorylated p38 MAPK and nonphosphoryated p38 MAPK, or phosphorylated HSP27 to nonphosphoryated HSP27, with individual results of $n=6-7$ in each group. ${ }^{*}: p<0.05$ compared with ACh alone; ${ }^{* *}$ : $p<0.01$ compared with ACh alone; ${ }^{*}$ : not significant.

upregulated by CSs. Indeed, dexamethasone reduced the degree of 38 MAPK activation induced by ACh, but in $\mathrm{MKP}-1^{-/-}$mice, there was no effect of dexamethasone on $\mathrm{p} 38 \mathrm{MAPK}$ activation. These results support the concept that the effect of CSs on contractile responses results from the modulation of MKP-1 expression.

We also demonstrated that in ozone-induced enhancement of the cholinergic contractile responses, a similar situation exists. This enhanced response was inhibited by a p38 MAPK inhibitor and the suppressive effect of CS may also be due to an increase in MKP-1 expression, since the ozone-enhanced contractile responses observed in $\mathrm{MKP}-1^{-/-}$mice was not affected by CSs. In MKP-1 ${ }^{-/-}$mice, ozone exposure not only caused an enhancement of the maximal contractile response, but also caused a significant leftward shift of the ACh doseresponse curve, indicating an enhanced sensitivity of the contractile response. This indicates that there may be other kinases, apart from p38 MAPK, under the control of MKP-1 that could determine the sensitivity of the isometric contractile response.

Our studies relate to an understanding of the mechanisms by which ozone exposure can lead to airway hyperresponsiveness in vivo. They indicate that an increase in the ASM contractile response may be an important contributory factor. This may occur through the activation of oxidative stress as, in a previous study, we have shown that pre-treatment of mice with an antioxidant, $\mathrm{N}$-acetylcysteine, prior to ozone exposure prevented the increased isometric contractile response (unpublished observations). Furthermore, the present study shows that p38 MAPK may contribute to the enhanced contractile response, as demonstrated by the increased activation of p38 in ASM and by the inhibitory effect of a p38 MAPK inhibitor. It must be noted that, in the baseline state, there is already activation of p38 MAPK that is important in regulating the maximal isometric contractile response to receptor-mediated contraction induced by ACh or 5-HT. 
a)

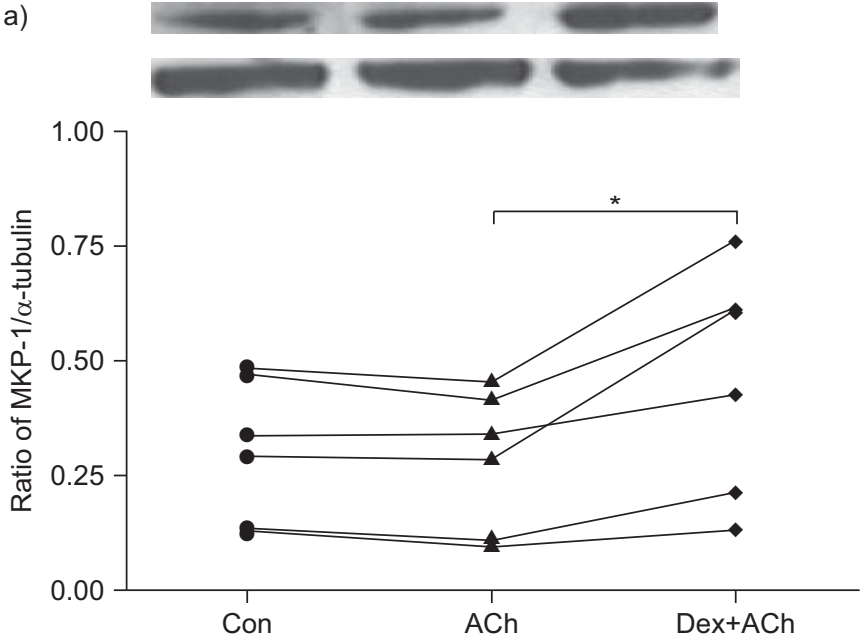

b)

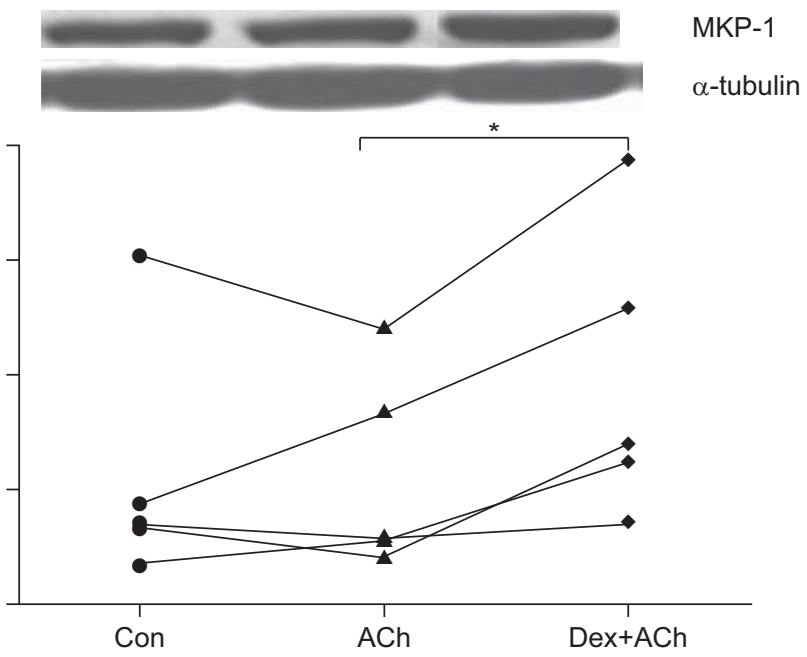

FIGURE 7. Representative Western blot analysis of mitogen-activated protein kinase phosphatase (MKP)- 1 and $\alpha$-tubulin under control (Con) conditions, after addition of acetylcholine (ACh; $\left.10^{-3} \mathrm{M}\right)$, and after $\mathrm{ACh}\left(10^{-3} \mathrm{M}\right)$ and dexamethasone (Dex; $10^{-6} \mathrm{M}$ ) to bronchial tissues from a) air- and b) ozone-exposed mice. *: $\mathrm{p}<0.05$.

The mechanisms by which p38 MAPK could regulate ASM contractile response are unclear. This activation is observed in the baseline state when the muscle is maximally contracted by ACh and also by other receptor-mediated constrictors, such as 5-HT. This would support the notion that the contractile response itself may activate p38 MAPK pathways. An enhanced maximal contractile response to ACh was observed after exposure of mice to ozone, and p38 MAPK activation underlied this augmentation. HSP27 could be one of the downstream effectors of p38 MAPK, since the p38 MAPK inhibitor we used inhibited HSP27 phosphorylation. In studies of vascular smooth muscle, p38 MAPK modulated actin organisation, and HSP27 was shown to inhibit actin polymerisation in a phosphorylation-dependent manner and mediated the rearrangement of actin [23]. Phosphorylation of HSP27 in ASM in response to the cholinergic agonist carbachol has been previously shown [24], together with tyrosine phosphorylation of p38 MAPK. p38 MAPK can also phosphorylate other nonmuscle proteins, such as the actin- and myosin-binding protein caldesmon, which is important in endothelial cytoskeletal remodelling and migration [25], and in urokinase-induced smooth muscle cell migration [26]. Interestingly, the idea that p38 MAPK may be important in promoting actin filament capping and shortening of actin filaments by nonphosphorylated HSP27 has been proposed [7]. Thus, p38 MAPK has been related to ASM function, including tissue mechanics, cell migration and proliferation, and gene expression [27].

Activated p38 MAPK directly phosphorylates and activates MK-2, MK-3 and MK-5 [28]. We now demonstrate that, downstream of p38 MAPK, at least MK-2 can regulate the contractile response of the airways to $\mathrm{ACh}$, using a selective inhibitor of MK-2. Similar results have been demonstrated in the inhibitory effect of lipopolysaccharide-induced TNF- $\alpha$ production by monocytes [22].

The inhibition of phosphorylation of p38 MAPK by SB239063, which we have demonstrated here, has been shown previously by other groups $[29,30]$. Additional studies have demonstrated that p38 $\alpha$ can autophosphorylate [31] and transphosphorylate [32], and another p38 MAPK inhibitor, SB203508, inhibits the enzymatic activity of both activated and unactivated forms of p38 $\alpha$ [33].

CSs have been shown to have multiple effects on smooth muscle function, such as uncoupling of H1-histamine receptors [34] or a reduction in muscarinic receptor expression [35]; in addition, they could increase ASM relaxation by interfering with $\beta_{2}$-adrenoceptor pathways [36]. In this study, dexamethasone inhibited the maximal isometric contractile response to $\mathrm{ACh}$, both in the baseline state and after exposure to an oxidant stress in wild-type mice, through a p38 MAPKdependent pathway. We showed that dexamethasone could upregulate MKP-1 in the bronchial rings within $1 \mathrm{~h}$ of incubation, which may in turn regulate p38 MAPK activity. However, dexamethasone was ineffective in inhibiting bronchial smooth muscle contraction in $\mathrm{MKP}^{-1^{-/}}$mice, supporting the concept that p38 MAPK could be an important mechanism by which CSs could be inhibiting the contractile responses. This may due to the failure of dexamethasone to induce the expression of MKP-1 in bronchial smooth muscle from $\mathrm{MKP}-1^{-/-}$mice. By promoting the expression of MKP-1 in both air- and ozone-exposed mice, dexamethasone can inhibit the activity of p38 MAPK. We confirmed that dexamethasone inhibited p38 MAPK phosphorylation in airand ozone-exposed wild-type mice, but not in air- and ozoneexposed $\mathrm{MKP}^{-1 /-}$ mice. This could also explain why dexamethasone could not inhibit HSP27 phosphorylation, which is associated with smooth muscle contraction. The potential direct effect of CSs has also been demonstrated in canine ASM cells, where CSs increased force fluctuationinduced relengthening through an inhibition of p38 MAPK and enhancement of MKP-1 [37].

In summary, the inhibition of p38 MAPK activation by SB239063 and by dexamethasone could lead to a reduction of the maximal ASM isometric contraction due to ACh, and this was dependent on the expression of MKP-1. p38 MAPK 
phosphorylation of certain muscle and nonmuscle proteins may contribute to the maximal contractile response.

\section{SUPPORT STATEMENT}

The study was supported by a Wellcome Trust grant (083905) to K.F. Chung and by a scholarship from the China Scholarship Council to F. Li.

\section{STATEMENT OF INTEREST}

A statement of interest for this study can be found at www.erj. ersjournals.com/site/misc/statements.xhtml

\section{ACKNOWLEDGEMENTS}

We thank Pfizer Pharmaceuticals (Sandwich, UK) for the provision of the MK-2 inhibitor PF-3644022 and Bristol-Myers Squibb (New York, $\mathrm{NY}$, USA) for the use of the MKP-1/- mice.

\section{REFERENCES}

1 Kumar S, Boehm J, Lee JC. p38 MAP kinases: key signalling molecules as therapeutic targets for inflammatory diseases. Nat Rev Drug Discov 2003; 2: 717-726.

2 Adcock IM, Chung KF, Caramori G, et al. Kinase inhibitors and airway inflammation. Eur J Pharmacol 2006; 533: 118-132.

3 Cao W, Sohn UD, Bitar KN, et al. MAPK mediates PKC-dependent contraction of cat esophageal and lower esophageal sphincter circular smooth muscle. Am J Physiol Gastrointest Liver Physiol 2003; 285: G86-G95.

4 Bitar KN. HSP27 phosphorylation and interaction with actinmyosin in smooth muscle contraction. Am J Physiol Gastrointest Liver Physiol 2002; 282: G894-G903.

5 Yamboliev IA, Hedges JC, Mutnick JL, et al. Evidence for modulation of smooth muscle force by the p38 MAP kinase/ HSP27 pathway. Am J Physiol Heart Circ Physiol 2000; 278: H1899-H1907.

6 Gerthoffer WT. Signal-transduction pathways that regulate visceral smooth muscle function. III. Coupling of muscarinic receptors to signaling kinases and effector proteins in gastrointestinal smooth muscles. Am J Physiol Gastrointest Liver Physiol 2005; 288: G849-G853.

7 Lakser OJ, Lindeman RP, Fredberg JJ. Inhibition of the p38 MAP kinase pathway destabilizes smooth muscle length during physiological loading. Am J Physiol Lung Cell Mol Physiol 2002; 282: L1117-L1121.

8 Williams AS, Issa R, Durham A, et al. Role of p38 mitogenactivated protein kinase in ozone-induced airway hyperresponsiveness and inflammation. Eur J Pharmacol 2008; 600: 117-122.

9 Nath P, Leung SY, Williams A, et al. Importance of p38 mitogenactivated protein kinase pathway in allergic airway remodelling and bronchial hyperresponsiveness. Eur J Pharmacol 2006; 544: 160-167.

10 Duan W, Chan JH, McKay K, et al. Inhaled p38 $\alpha$ mitogen-activated protein kinase antisense oligonucleotide attenuates asthma in mice. Am J Respir Crit Care Med 2005; 171: 571-578.

11 Jones GL, O'Byrne PM, Pashley M, et al. Airway smooth muscle responsiveness from dogs with airway hyperresponsiveness after $\mathrm{O}_{3}$ inhalation. J Appl Physiol 1988; 65: 57-64.

12 Amrani $Y$, Martinet N, Bronner C. Potentiation by tumour necrosis factor- $\alpha$ of calcium signals induced by bradykinin and carbachol in human tracheal smooth muscle cells. Br J Pharmacol 1995; 114: 4-5.

13 Hakonarson $\mathrm{H}$, Halapi E, Whelan R, et al. Association between IL$1 \beta /$ TNF- $\alpha$-induced glucocorticoid-sensitive changes in multiple gene expression and altered responsiveness in airway smooth muscle. Am J Respir Cell Mol Biol 2001; 25: 761-771.
14 Abraham SM, Lawrence T, Kleiman A, et al. Antiinflammatory effects of dexamethasone are partly dependent on induction of dual specificity phosphatase 1. J Exp Med 2006; 203: 1883-1889.

15 Abraham SM, Clark AR. Dual-specificity phosphatase 1: a critical regulator of innate immune responses. Biochem Soc Trans 2006; 34: 1018-1023.

16 Issa $\mathrm{R}, \mathrm{Xie} \mathrm{S}, \mathrm{Khorasani} \mathrm{N}$, et al. Corticosteroid inhibition of growth-related oncogene protein- $\alpha$ via mitogen-activated kinase phosphatase-1 in airway smooth muscle cells. J Immunol 2007; 178: 7366-7375.

17 Lasa M, Abraham SM, Boucheron C, et al. Dexamethasone causes sustained expression of mitogen-activated protein kinase (MAPK) phosphatase 1 and phosphatase-mediated inhibition of MAPK p38. Mol Cell Biol 2002; 22: 7802-7811.

18 Quante T, Ng YC, Ramsay EE, et al. Corticosteroids reduce IL-6 in ASM cells via up-regulation of MKP-1. Am J Respir Cell Mol Biol 2008; 39: 208-217.

19 Dorfman K, Carrasco D, Gruda M, et al. Disruption of the erp/ $m k p-1$ gene does not affect mouse development: normal MAP kinase activity in ERP/MKP-1-deficient fibroblasts. Oncogene 1996; 13: 925-931.

20 Williams AS, Leung SY, Nath P, et al. Role of TLR2, TLR4, and MyD88 in murine ozone-induced airway hyperresponsiveness and neutrophilia. J Appl Physiol 2007; 103: 1189-1195.

21 Liu JQ, Yang D, Folz RJ. A novel bronchial ring bioassay for the evaluation of small airway smooth muscle function in mice. Am J Physiol Lung Cell Mol Physiol 2006; 291: L281-L288.

22 Mourey RJ, Burnette BL, Brustkern SJ, et al. A benzothiophene inhibitor of mitogen-activated protein kinase-activated protein kinase 2 inhibits tumor necrosis factor alpha production and has oral anti-inflammatory efficacy in acute and chronic models of inflammation. J Pharmacol Exp Ther 2010; 333: 797-807.

23 Huot J, Houle F, Marceau F, et al. Oxidative stress-induced actin reorganization mediated by the $\mathrm{p} 38$ mitogen-activated protein kinase/heat shock protein 27 pathway in vascular endothelial cells. Circ Res 1997; 80: 383-392.

24 Larsen JK, Yamboliev IA, Weber LA, et al. Phosphorylation of the 27-kDa heat shock protein via p38 MAP kinase and MAPKAP kinase in smooth muscle. Am J Physiol 1997; 273: L930-L940.

25 Mirzapoiazova T, Kolosova IA, Romer L, et al. The role of caldesmon in the regulation of endothelial cytoskeleton and migration. J Cell Physiol 2005; 203: 520-528.

26 Goncharova EA, Vorotnikov AV, Gracheva EO, et al. Activation of p38 MAP-kinase and caldesmon phosphorylation are essential for urokinase-induced human smooth muscle cell migration. Biol Chem 2002; 383: 115-126.

27 Gerthoffer WT, Singer CA. MAPK regulation of gene expression in airway smooth muscle. Respir Physiol Neurobiol 2003; 137: 237-250.

28 Gaestel M, Mengel A, Bothe U, et al. Protein kinases as small molecule inhibitor targets in inflammation. Curr Med Chem 2007; 14: 2214-2234.

29 Galan A, Garcia-Bermejo ML, Troyano A, et al. Stimulation of p38 mitogen-activated protein kinase is an early regulatory event for the cadmium-induced apoptosis in human promonocytic cells. J Biol Chem 2000; 275: 11418-11424.

30 Matsuguchi T, Musikacharoen T, Ogawa T, et al. Gene expressions of Toll-like receptor 2, but not Toll-like receptor 4, is induced by LPS and inflammatory cytokines in mouse macrophages. J Immunol 2000; 165: 5767-5772.

31 Ge B, Gram H, Di Padova F, et al. MAPKK-independent activation of p38alpha mediated by TAB1-dependent autophosphorylation of p38 $\alpha$. Science 2002; 295: 1291-1294.

32 Diskin R, Askari N, Capone R, et al. Active mutants of the human p38 $\alpha$ mitogen-activated protein kinase. J Biol Chem 2004; 279 : 47040-47049.

33 Frantz B, Klatt $\mathrm{T}$, Pang $\mathrm{M}$, et al. The activation state of $\mathrm{p} 38$ mitogen-activated protein kinase determines the efficiency of ATP 
competition for pyridinylimidazole inhibitor binding. Biochemistry 1998; 37: 13846-13853.

34 Hardy E, Farahani M, Hall IP. Regulation of histamine H1 receptor coupling by dexamethasone in human cultured airway smooth muscle. Br J Pharmacol 1996; 118: 1079-1084.

35 Nabishah BM, Morat PB, Kadir BA, et al. Effect of steroid hormones on muscarinic receptors of bronchial smooth muscle. Gen Pharmacol 1991; 22: 389-392.
36 Mak JC, Hisada T, Salmon M, et al. Glucocorticoids reverse IL-1 $\beta$ induced impairment of $\beta$-adrenoceptor-mediated relaxation and up-regulation of G-protein-coupled receptor kinases. $\mathrm{Br} \mathrm{J}$ Pharmacol 2002; 135: 987-996.

37 Lakser OJ, Dowell ML, Hoyte FL, et al. Steroids augment relengthening of contracted airway smooth muscle: potential additional mechanism of benefit in asthma. Eur Respir J 2008; 32: 1224-1230. 